University of Nebraska - Lincoln

DigitalCommons@University of Nebraska - Lincoln

Great Plains Wildlife Damage Control Workshop Wildlife Damage Management, Internet Center Proceedings

1973

\title{
Preliminary Interpretations of Coyote Population Mechanics with Some Management Implications
}

Frederick F. Knowlton

Bureau of Sport Fisheries and Wildlife

Follow this and additional works at: https://digitalcommons.unl.edu/gpwdcwp

Part of the Environmental Health and Protection Commons

Knowlton, Frederick F., "Preliminary Interpretations of Coyote Population Mechanics with Some Management Implications" (1973). Great Plains Wildlife Damage Control Workshop Proceedings. 472. https://digitalcommons.unl.edu/gpwdcwp/472

This Article is brought to you for free and open access by the Wildlife Damage Management, Internet Center for at DigitalCommons@University of Nebraska - Lincoln. It has been accepted for inclusion in Great Plains Wildlife Damage Control Workshop Proceedings by an authorized administrator of DigitalCommons@University of Nebraska - Lincoln. 


\section{PRELIMINARY INTERPRETATIONS OF COYOTE POPULATION MECHANICS WITH SOME MANAGEMENT IMPLICATIONS}

By Frederick F. KNOWLton

Made in United States of America

Reprinted from The Journal of Wildlife Management

Vol. 36, No. 2, April 1972
pp. $369-382$ 


\title{
PRELIMINARY INTERPRETATIONS OF COYOTE POPULATION MECHANICS WITH SOME MANAGEMENT IMPLICATIONS
}

\author{
FREDERICK F. KNOWLTON, Bureau of Sport Fisheries and Wildlife, San Antonio, Texas
}

Abstract: The need for control of coyote (Canis latrans) depredations and a simultaneous demand for recognition of the aesthetic and ecologic values of the species create a conflict in resource utilization that should be resolved through more intensive management. A coyote population model is proposed from current estimates of density, reproduction, population structure, and mobility. Densities of 0.5 to 1.0 coyote per square mile are frequently suggested, with occasional estimates of 4.0 or more per square mile. Reproductive rates fluctuate as functions of the proportion of females that ovulate, the average number of ova shed, and in utero viabilities. Average litter sizes of 4.3 to 6.9 seemed to be inversely related to population density. Age structure of unexploited populations suggests a 40 percent annual mortality for coyotes over 1 year of age, with relatively high survival rates betiveen 4 and 8 years of age. Movement patterns are not well understood, particularly with regard to home range and dispersal, although indications are that females may be prone to longer treks than males. Implications of the coyote population model that may be applicable in control technology, particularly with respect to general population suppression, temporary and local problems, intensive reductional programs, and efforts to reduce infiltration rates into high risk areas, are discussed.

Until recently, management of the larger North American carnivores has been oriented toward removal of animals or species where their presence appeared to jeopardize human safety or toward economic or sporting interests. Now these same animals are also in demand for aesthetic and recrea- tional purposes. The current ambiguity presents a duality in management that can be achieved only through a better understanding of the entire spectrum of species values, more intimate biological knowledge, and more precise techniques. In short, this means more intensive management. 
Population models are useful tools in unclerstanding population processes, systematizing ecologic relationships, and for devising and implementing management practices. In the latter case, such models could serve as a basis for providing sustained yields of game and furbearing animals, preventing agricultural depredations, limiting numbers below epizootic thresholds, and encouraging populations for aesthetic enjoyment. However, demographic models for carnivores are scarce. This discussion will explore some parameters of coyote populations (namely density, reproduction, population structure, and movements), formulate a provisional population model, and suggest some implications for management of coyotes.

The findings and interpretations presented here reflect the cooperation and assistance rendered by District Field Assistants and their supervisors in the Division of Wildlife Services in Texas. Credits are also due C. J. Carley and R. T. McBride for their efforts and critiques, and to Ann Jones for editorial review of the manuscript.

\section{POPULATION PARAMETERS}

\section{Densities}

The relatively low densities of coyotes create special sampling problems that are compounded by the mobility and behavioral traits of the species. Field personnel working closely with coyotes invariably form opinions concerning relative numbers and make subjective judgments about changes in abundance. These estimates may be satisfactory for purposes of animal control, but they are scarcely quantitative and are subject to inherent biases of the observers. Eventually, more precise means of population enumeration will be needed if more intensive coyote management is to be achieved. Several methods for estimating relative numbers of coyotes have been sug-

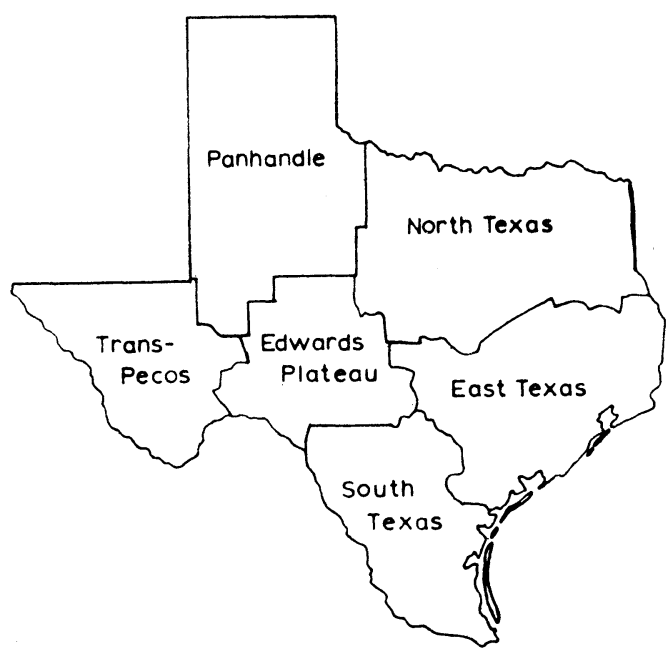

Fig. 1. Six geographic areas of Texas.

gested and tried, including track counts, scat counts, elicited howling responses, scent post visitations, aerial surveys, and several catch-per-unit-effort techniques, but, to my knowledge, none has been adequately evaluated (Robinson 1961, Pimlott and Joslin 1968, Clark 1972, Lueth undated, Linhart and Knowlton, unpublished data).

A technique we used to quantify the relative abundance of coyotes employed Humane Coyote-getters (Robinson 1943) set in standard lines-50 getters set at 0.3mile intervals for a period of 10 days in the fall. The Humane Coyote-getter has been largely replaced now by the similar $M-44$ device which utilizes a coil spring to expel the toxicant rather than an explosive charge. The results, a kill type of trap-night data, provided a measure of relative abundance of coyotes in several areas of Texas (Fig. 1) and avoided most observer bias. The data (Table 1) suggest that coyotes are much more abundant in South Texas (average catch of more than 50 coyotes per standard coyote-getter line) than in the Panhandle (10-15 coyotes per line), whereas coyotes 
Table 1. Indices of coyote abundance in four regions of Texas, 1965-68, as determined by the mean number of units discharged by coyotes along standard coyote getter lines."

\begin{tabular}{|c|c|c|c|c|}
\hline A wris & 1965 & 1966 & 1967 & 1968 \\
\hline Panhandle. & $10.1(8)^{b}$ & $13.5(8)$ & $11.7(7)$ & $12.2(8)$ \\
\hline lidwards l'lateaul & $0.2(5)$ & $0.4(5)$ & $0.8(5)$ & $0.0(5)$ \\
\hline South Texas & $35.2(8)$ & $56.0(6)$ & $68.8(5)$ & $51.5(6)$ \\
\hline North Texas & $19.2(2)$ & $19.1(2)$ & $14.9(2)$ & $13.6(2)$ \\
\hline
\end{tabular}

Standard coyote-getter line was comprised of 50 units set at 0.3 -mile intervals along ranch roads for 10 consecutive nights (hence each line represents 500 getter-nights).

D Number of lines in parentheses.

are obviously scarce in the Edwards Plateau (0-1 coyote per line).

Ideas of absolute densities for coyotes are obscure and frequently limited to educated guesses. A breeding population of 1.5 per square mile and a postwhelping population of 2.0 per square mile in a six-county area of Kansas was estimated by Gier (1968), and Bennitt (1948) calculated densities of 0.07 to 0.56 per square mile in various areas of Missouri. After intensive efforts at tagging, release, and recapture, Clark (1972) estimated postwhelping season densities in Curley Valley, Utah, at one coyote per 2 to 4 square miles. Population counts, incuding visibly marked animals, from fixed- and rotary-wing aircraft led C. H. Nellis (personal communication) to consider 25 to 40 coyotes per township realistic for the area near Rochester, Alberta. From our work in Texas, it is apparent that coyotes are scarce in the Edwards Plateau, whereas parts of South Texas may average 4 to 6 per square mile in the fall. The latter estimates are derived empirically from results of standard coyote-getter lines and tagging studies. In one instance, 46 adult coyotes were trapped, tagged, and released in a 40-square-mile area in the spring (just prior to whelping), when populations were assumed to be most sedentary. However, 2 weeks later density estimates were abandoned when only one tagged coyote was among the 56 animals recovered from an aerial hunt, even though 40 addi- tional square miles surrounding the tagging site were included in the recapture effort. In another 30-square-mile area, 37 coyote pups from five dens were tagged. With adjustments for one den known to be missed, the parents of the pups involved, and an assumed equal number of nonbreeding adults (discussed in the section on reproduction), a minimum density of 2.3 coyotes per square mile was derived.

Although admittedly vague, coyote densities appear to range as high as 5 to 6 per square mile under extremely favorable conditions, with 0.5 to 1.0 per square mile seemingly realistic over a large portion of their range.

\section{Reproduction}

Variations in performance at any point in the reproductive process can change the reproductive efficiency of any population. Among coyotes, the percentage of females capable of breeding, the ovulation rate, the degree of success in implanting, and in utero viability are important.

The percentage of female coyotes that are sexually mature and that successfully whelp is perhaps one of the more important variables in the reproductive capacity of local populations. Studies of captive coyotes indicate that 35 percent may experience estrus in their first year, the remainder not becoming sexually mature until 20 to 22 months of age (J. J. Kennelly, personal communication). Field observations in Texas suggest 
Table 2. Comparison of coyole reproductive performance in four population somplas fiom Texas."

\begin{tabular}{|c|c|c|c|c|c|c|}
\hline \multirow[b]{2}{*}{ COUNTY } & \multirow[b]{2}{*}{ YEAR } & \multicolumn{3}{|c|}{ Foneaters } & \multirow[b]{2}{*}{ 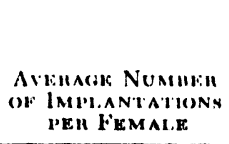 } & \multirow[b]{2}{*}{ 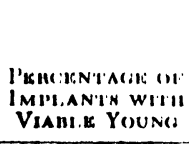 } \\
\hline & & $\begin{array}{c}\text { Number } \\
\text { Examined }\end{array}$ & $\begin{array}{l}\text { Percentage } \\
\text { Ovulating }\end{array}$ & $\begin{array}{l}\text { Percerntikg } \\
\text { with lm- } \\
\text { plantation } \\
\text { Sites }\end{array}$ & & \\
\hline Zapata & 1967 & 37 & 62 & 54 & $5.7(21)^{b}$ & 86 \\
\hline Starr & 1968 & 29 & 48 & 48 & $5.4(14)$ & 93 \\
\hline Duval & 1968 & 36 & 59 & 50 & $4.8(18)$ & - \\
\hline Crane & 1969 & 21 & 81 & 67 & $6.6(14)$ & 80 \\
\hline Mean & & & 62 & 54 & 5.6 & 87 \\
\hline
\end{tabular}

Zapata, Starr, and Crane county samples taken April 9-21 (at whelping time) and Duval sample collected postpartum (May through July).

b Number of females with inplantations.

that 1-year-old females usually do not make an appreciable contribution to the general productivity, but under some circumstances they may. In Kansas, Gier (1968) reported that in some years less than 10 percent of this age group becomes sexually active but that when rodents are abundant, as high as 70 percent of the short yearlings may breed. In the absence of more definitive data, the discussion here will not distinguish between contributions from specific age components but will consider the entire female portion of the population.

Gier (1968) suggested that during favorable conditions in Kansas, 75 percent of the female coyotes were sexually active, but less than 36 percent might be capable of breeding during less desirable conditions. Calculations based on data presented by Linhart et al. (1968) reveal that 32 to 91 percent of the females ovulated, with an average of 57 percent for 15 study areas. Our data from Texas (Table 2) show differences of 48 to 81 percent of the females capable of breeding (ovulating). Most of the variation appears to result from the frequency with which females become sexually mature in their first year of life and, to a lesser degree, from the breeding capabilities of older coyotes.

Effective reproduction, however, cannot be measured by ovulations alone. Examina- tions of female reproductive tracts during late pregnancy suggest that an average of 8 percent, and as high as 14 percent, of the females may ovulate without implanting embryos (Table 2). At the same time, the mean number of recognized implantation sites ranged from 4.8 to 6.6 per female $(\bar{x}=$ 5.6 ), with 80 to 93 percent ( $\bar{x}=87$ percent) represented by viable young.

Data reported by professional trappers (District Field Assistants from the Division of Wildlife Services) who routinely examined reproductive tracts suggested that average litter size may be inversely related to population density (Tables 3-5). The average number of unborn young reported undoubtedly represents resorbing in utero fatalities, as well as viable young, since the number of uterine swellings constitutes the recorded observation. On the other hand, the average number of pups reported per den is typically smaller than the average number of unborn young as a result of uterine and postnatal mortalities, as well as failure to recover all young from each litter, particularly among older pups that may be split between two or more burrows. Similar observations were reported by Hamlett (1938). In the present study, sample sizes less than 10 were considered inadequate and generally excluded from the discussion.

Average litter sizes reported from North 


\begin{tabular}{lll}
$\begin{array}{l}\text { Table 3. Average coyote litter size from two regions of } \\
\text { Texas as indicated by unborn young and pups recovered } \\
\text { from dens. }\end{array}$ \\
\hline Source & Nonth TExAs & PANHANDLE \\
\hline $\begin{array}{l}\text { Uterine swellings } \\
1967\end{array}$ & $6.7(18)^{\mathrm{b}}$ & $5.3(15)$ \\
1968 & $-(2)$ & $6.5(16)$ \\
1969 & $6.8(43)$ & $5.3(42)$ \\
& & \\
Whelps per den & & \\
1967 & $5.7(43)$ & $5.2(71)$ \\
1968 & $5.0(41)$ & $5.0(85)$ \\
1969 & $5.4(53)$ & $5.0(85)$ \\
\hline
\end{tabular}

- Based on reports submitted by Division of Wildlife Services personnel.

b Sample sizes (in parentheses) represent number of pregnant females or dens reported.

Texas were consistently higher than from other areas of the state (Tables 3 and 4). Empirical information indicates that coyote densities in this area are lower than in either the Panhandle or South Texas. (Density data for this area presented in Table 1 are not representative, since the only two census lines run were located adjacent to the western border.) In South Texas, where coyotes are extremely abundant, reported litter sizes averaged only 4.3. In the Uvalde section of South Texas, where coyote numbers are drastically reduced by intensive control efforts, the average litter size was 6.9. Furthermore, if the seven counties providing most of the data on litter size from South Texas are ranked empirically in relation to the effectiveness of the respective coyote control programs (and presumably inversely to population density), the average litter sizes reported with one exception, appear in a similar order (Table $5)$. Thus, the inverse relationship between population density and average litter size reported for many other species (Errington 1946, Christian 1956, 1959, and other authors) also seems realistic for coyotes.

Despite the obvious increased productivity that can be achieved through larger litters, I believe the greatest adjustments
Table 4. Comparison of average litter sizes in six areas of Texas."

\begin{tabular}{|c|c|c|}
\hline AREA & $\begin{array}{c}\text { NUMBER OF } \\
\text { PREGNANT } \\
\text { FEMALES } \\
\text { EXAMINED }\end{array}$ & $\begin{array}{c}\text { AVERAGE NUM- } \\
\text { BER OF UTERINE } \\
\text { SWELLINGS PER } \\
\text { FEMALE }\end{array}$ \\
\hline North Texas & 43 & 6.8 \\
\hline Panhandle & 42 & 5.3 \\
\hline \multicolumn{3}{|l|}{ South Texas } \\
\hline Excluding Uvalde & 6.3 & 4.3 \\
\hline Uvalde area & 21 & 6.9 \\
\hline East Texas & 20 & 5.2 \\
\hline Trans-Pecos & 12 & 5.1 \\
\hline
\end{tabular}

${ }^{\text {a From reports submitted by Division of Wildlife Ser- }}$ vices personnel.

in productivity of local populations result from significant changes in the percentage of females capable of bearing young, with the percentage of juveniles that become sexually mature in their first year of life particularly important. However, the factors regulating the frequency of pregnancy among coyotes also influence litter size, and the conditions that lead to higher pregnancy rates probably also favor larger litter sizes.

\section{Population Structure}

Discussion of the sex and age composition of coyote populations should be prefaced with the realization that population structure is not static, particularly with respect to the segment comprised of juveniles. Thus, any accumulative type of pop-

Table 5. Comparison of average litter sizes from seven South Texas counties in relation to control efforts."

\begin{tabular}{|c|c|c|c|}
\hline $\begin{array}{l}\text { INTEN- } \\
\text { SITY OF } \\
\text { CONTROL } \\
\text { EFFORT }\end{array}$ & County & $\begin{array}{c}\text { NUMBER OF } \\
\text { PREGNANT } \\
\text { FEMALES } \\
\text { EXAMINED }\end{array}$ & $\begin{array}{c}\text { AVERAGE } \\
\text { NUMBER OF } \\
\text { UTERINE } \\
\text { SWELLINGS } \\
\text { PER FEMALE }\end{array}$ \\
\hline \multirow[t]{3}{*}{ Intensive } & Uvalde & 10 & 6.2 \\
\hline & Zavala & 8 & 8.9 \\
\hline & Dimmit & 12 & 6.4 \\
\hline \multirow[t]{2}{*}{ Moderate } & Jim Wells & 21 & 5.3 \\
\hline & Hidalgo & 11 & 3.7 \\
\hline \multirow[t]{2}{*}{ Light } & Jim Hogg & 17 & 4.2 \\
\hline & Duval & 11 & 2.8 \\
\hline
\end{tabular}

a From reports submitted by Division of Wildlife Services personnel. 
Table 6. Adult age frequencies by sex among samples of coyote populations from four areas.

\begin{tabular}{|c|c|c|c|c|c|c|c|c|}
\hline 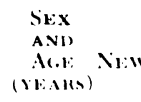 & 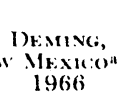 & $\begin{array}{l}\text { Amwacis, } \\
\text { AmizoNA" } \\
\text { 196i7 }\end{array}$ & 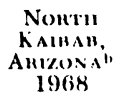 & 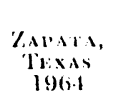 & 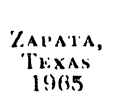 & $\begin{array}{c}\text { ZAPATA, } \\
\text { TEXAs } \\
\text { 19Gio }\end{array}$ & $\begin{array}{c}\text { ZAPATA, } \\
\text { TexAs } \\
\text { 19667 }\end{array}$ & 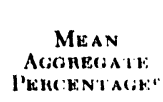 \\
\hline \multicolumn{9}{|l|}{ Fimales } \\
\hline 1 & 12 & 15 & 8 & 3 & 5 & 10 & $2: 3$ & 50.3 \\
\hline 2 & 8 & 6 & 1 & 1 & 4 & 1 & 4 & 15.4 \\
\hline 3 & 4 & 5 & 6 & 0 & 2 & 2 & 2 & 11.9 \\
\hline 4 & 4 & 1 & 1 & 0 & 3 & 1 & 1 & 5.9 \\
\hline 5 & 3 & 1 & 2 & 0 & 1 & 2 & 2 & 5.8 \\
\hline 6 & 4 & 0 & 0 & () & 1 & 1 & 0 & 2.8 \\
\hline 7 & 2 & 0 & 0 & 0 & 2 & 1 & 2 & 3.6 \\
\hline 8 & 1 & 0 & 1 & 0 & 0 & 0 & 0 & 1.1 \\
\hline 9 & 0 & 0 & 0 & 0 & 0 & 1 & 2 & 1.3 \\
\hline 10 & 0 & 1 & 0 & 0 & 1 & 0 & 0 & 1.2 \\
\hline 11 & 0 & 0 & 0 & 0 & 0 & 1 & 0 & 0.5 \\
\hline 12 & 0 & 0 & 0 & 0 & 0 & 0 & 0 & 0.0 \\
\hline Total & 38 & 29 & 19 & 4 & 19 & 26 & 36 & \\
\hline \multicolumn{9}{|l|}{ Males } \\
\hline 1 & 13 & 17 & 10 & 4 & 12 & 8 & 4 & 34.3 \\
\hline 2 & 4 & 16 & 6 & 2 & 8 & 7 & 4 & 24.2 \\
\hline 3 & 5 & 6 & 1 & 1 & 5 & 1 & 2 & 10.3 \\
\hline 4 & 7 & 6 & 4 & 0 & 0 & 3 & 0 & 8.0 \\
\hline 5 & 4 & 2 & 1 & 1 & 0 & 0 & 3 & 6.7 \\
\hline 6 & 4 & 1 & 0 & 3 & 0 & 0 & 0 & 4.3 \\
\hline 7 & 6 & 1 & 2 & 0 & 0 & 2 & 0 & 4.5 \\
\hline 8 & 3 & 1 & 0 & 0 & 2 & 2 & 0 & 3.5 \\
\hline 9 & 1 & 0 & 0 & 1 & 0 & 0 & 0 & 1.3 \\
\hline 10 & 0 & 0 & 1 & 1 & 0 & 0 & 0 & 1.6 \\
\hline 11 & 0 & 0 & 0 & 0 & 0 & 0 & 0 & 0.0 \\
\hline 12 & 0 & 0 & 0 & 1 & 0 & 0 & 0 & 1.0 \\
\hline Total & 47 & 50 & 25 & 14 & 27 & 23 & 13 & \\
\hline
\end{tabular}

- Data provided by S. B. Linhart, Denver Wildlife Research Center.

D Data provided by D. Juve, Division of Wildlife Services, Tucson, Arizona.

c Mean percentage of each group from each sample.

ulation sampling over an extended period (as might be obtained through routine control operations) is biased toward the more mobile segments of the population. Unless otherwise stated, aspects discussed here will refer to the adult portion of relatively unexploited coyote populations, with samples extracted in as brief a time as practical.

The age distribution among natural coyote populations was estimated through examination of cementum layers and relative size of the pulp cavity of canine teeth (Linhart and Knowlton 1967) in seven samples from four areas. (Table 6). A significant difference between the age structure of male and female segments of the populations apparently resulted from marked differences in 1-year-olds. No significant difference $\left(X^{2}, 6 \mathrm{df}=6.69\right)$ was noted between the age structure of the sexes when 1-yearolds were disregarded. The data were combined and a fourth degree polynomial, $Y=$ $71.5855-38.9838 X+8.3024 X^{2}-0.7599 X^{3}$ $+0.0248 X^{4}$, calculated $\left(R^{2}=0.88\right)$ to approximate the general age composition of the adult portion ( 1 year and older) of unexploited coyote populations (Fig. 2). These calculations suggest that in the ab- 


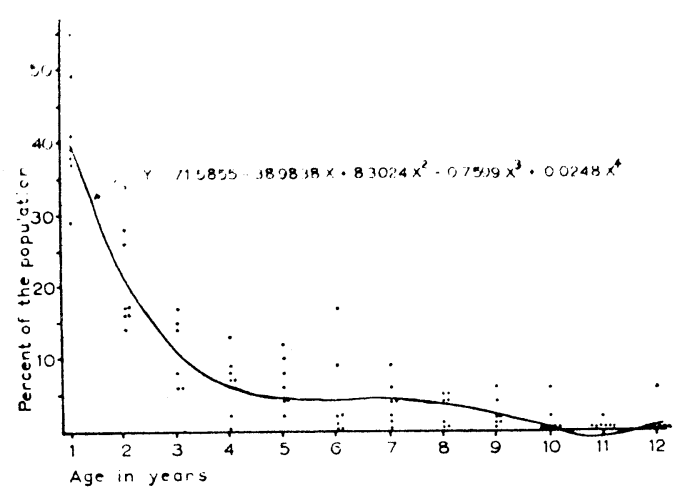

Fig. 2. Composite age distribution of adult coyotes.

sence of organized coyote control programs, more than 70 percent of spring (prewhelping) populations are less than 3 years old, and less than 5 percent exceed 9 years of age. In the fall, more than 80 percent of these populations are under 3 years old. These findings are in general agreement with those of Gier (1968) and Rogers (1965). The age structure also implies that mortality rates of coyotes 1 year and older may exceed 40 percent annually even when coyotes are not exploited. The decreasing annual mortality rate noted for successively older coyotes suggests that experience, learning or accepted social positions, or both, may be factors in survival, at least through 8 years of age. The oldest wild coyotes recorded, on the basis of cementum annuli, were a 14.5-year-old female from western Colorado (D. S. Balser, personal communication) and a 13.5-yearold male from Kinney County, Texas.

Differential behavior (to be discussed later) between adult males and females, as well as differences between juveniles and adults, complicates interpretations of sex and age ratios. On the basis of field examinations of coyotes recovered from standard coyote-getter lines in high density areas, it appears that juveniles comprise ahout half the fall populations, although a

\begin{tabular}{|c|c|c|c|c|c|}
\hline \multirow{2}{*}{$\begin{array}{l}\text { AREA } \\
\text { AND } \\
\text { YEAR }\end{array}$} & \multirow{2}{*}{$\begin{array}{c}\text { NUMBEH } \\
\text { EXAM- } \\
\text { INED }\end{array}$} & \multicolumn{2}{|c|}{ ADULTS } & \multicolumn{2}{|c|}{ JUVENILES } \\
\hline & & Females & Males & Females & Males \\
\hline \multicolumn{6}{|c|}{ Zapata County } \\
\hline 1965 & 87 & 20.7 & 35.6 & 20.7 & 23.0 \\
\hline 1966 & 154 & 24.7 & 25.3 & 22.7 & 27.3 \\
\hline 1967 & 111 & 23.4 & 19.8 & 31.5 & 25.2 \\
\hline 1968 & 100 & 27.0 & 21.0 & 24.0 & 28.0 \\
\hline \multicolumn{6}{|c|}{ Webb County } \\
\hline 1968 & 104 & 24.8 & 25.0 & 26.0 & 19.2 \\
\hline Avera & & 25.1 & 25.3 & 25.0 & 24.5 \\
\hline
\end{tabular}

- Based on body size and conformation, tooth eruption, and relative tooth wear as evaluated by the author or assistants, or both.

range of 44 to 57 percent has been noted (Table 7). This is in reasonable agreement with estimates that under conditions in South Texas, about 50 percent of the population normally breeds, producing average litters of 4.6 to 5.2 young. In southern New Mexico, Rogers (1965) found that pups comprised 53 percent of the fall population. Among samples taken during the spring, males typically predominate, presumably as a result of limited activity on the part of gravid females. This aspect persists even among samples obtained by aerial gunning from helicopters. Nevertheless, I believe that the sexes approximate a $1: 1$ ratio in the spring.

\section{Movements}

Reports of coyote mobility in the literature are restricted to accounts of a few individual coyotes (Young and Jackson 1951) and several tagging-recapture studies ( $F$. E. Garlough 1940, unpublished report, on file at the Denver Wildlife Research Center; Robinson and Cummings 1951; Robinson and Grand 1958). Unfortunately, 2- or 3 -point location analyses, particularly if made over extended intervals, do not readily lend themselves to distinguishing between 


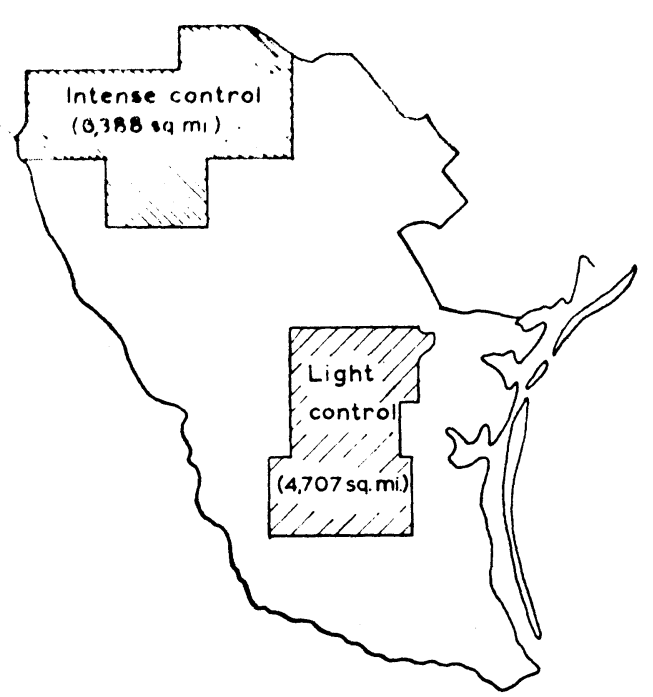

Fig. 3. Areas of light and intense coyote control in South Texas.

movements of individuals within established ranges and dispersal of animals seeking to establish themselves in new areas. Ironically, the paucity of information on coyote movement patterns has hampered and thwarted other studies of coyote biology and predator-prey relationships. Robinson and Cummings (19.51) arbitrarily assumed $7 \times$-scuare-mile home ranges (11-mile diancter) for coyotes. Current knowledge can scarcely take us further, although radiotracking studies now in progress should be cnlightening.

The other aspect of movement, dispersal, is perhaps more important in management schemes because it provides the mainspring for restocking areas where removal has been the primary objective of coyote management. Analyses of the animals recovered in control operations from portions of South Texas (Fig. 3) offered a unique opportunity to study aspects of dispersal. Some coyotes caught in the Uvalde area, where the control program is most intense, doubtless were residents that had previously eluded capture, but ingress from the dense populations in the surrounding areas contributed substantially to the catch. To the south, in the heart of the high coyote density area, appreciably larger numbers of coyotes were taken from an area of similar size, but the control effort was low in relation to the

Table 8. Percentage of distribution of the September-to-March catch of coyotes from areas of intensive and light control efforts in South Texas.

\begin{tabular}{|c|c|c|c|c|c|c|}
\hline $\begin{array}{l}\text { DegRee of } \\
\text { CONTROL } \\
\text { AND MONTH }\end{array}$ & $1963-64$ & $1964-65$ & $1965-66$ & $1966-67$ & $1967-68$ & Average \\
\hline Intensive & $(435)^{\wedge}$ & (413) & (479) & $(850)$ & $(502)$ & 一 \\
\hline September & 8 & 6 & 6 & 4 & $7^{\prime}$ & 6 \\
\hline October & 15 & 11 & 9 & 9 & 14 & 12 \\
\hline November & 14 & 15 & 11 & 16 & 16 & 14 \\
\hline December & 16 & 21 & 14 & 17 & 13 & 16 \\
\hline January & 23 & 25 & 27 & 27 & 17 & 24 \\
\hline February & 13 & 12 & 19 & 16 & 18 & 16 \\
\hline March & 12 & 11 & 13 & 12 & 14 & 12 \\
\hline Light & $(3,450)$ & $(2,516)$ & $(1,926)$ & $(2,437)$ & $(1,120)$ & - \\
\hline September & 9 & 10 & 12 & 12 & 5 & 10 \\
\hline October & 16 & 15 & 18 & 16 & 11 & 15 \\
\hline November & 21 & 15 & 20 & 16 & 20 & 18 \\
\hline December & 17 & 14 & 14 & 16 & 19 & 16 \\
\hline January & 16 & 16 & 10 & 15 & 17 & 15 \\
\hline February & 12 & 16 & 13 & 14 & 10 & 13 \\
\hline March & 10 & 14 & 12 & 11 & 16 & 13 \\
\hline
\end{tabular}

ample sizes in parentheses. 
Table 9. Percentage of catch, by month, comprised of females in areas of light and intensive control, 1966-67 and $1967-68$.

\begin{tabular}{|c|c|c|c|c|}
\hline \multirow[b]{2}{*}{$\begin{array}{c}\text { YEAR } \\
\text { AND } \\
\text { MONTH }\end{array}$} & \multicolumn{2}{|c|}{$\begin{array}{c}\text { INTENSIVE ControL } \\
\text { AREA }\end{array}$} & \multicolumn{2}{|c|}{ Light Control Area } \\
\hline & $\begin{array}{c}\text { Number of } \\
\text { Animals }\end{array}$ & $\begin{array}{l}\text { Percent- } \\
\text { age of } \\
\text { Females }\end{array}$ & $\begin{array}{l}\text { Number of } \\
\text { Animals }\end{array}$ & $\begin{array}{l}\text { Percent- } \\
\text { age of } \\
\text { Females }\end{array}$ \\
\hline \multicolumn{5}{|l|}{$1966-67$} \\
\hline September & 18 & 56 & 135 & 47 \\
\hline October & 79 & 48 & 346 & 45 \\
\hline November & 131 & 72 & 352 & 53 \\
\hline December & 153 & 75 & 365 & 46 \\
\hline January & 225 & 63 & 372 & 6.3 \\
\hline February & 138 & 60 & 328 & 48 \\
\hline March & 102 & 67 & 243 & 47 \\
\hline Total & 846 & 64.8 & 2,141 & 50.4 \\
\hline \multicolumn{5}{|l|}{$1967-68$} \\
\hline September & 38 & 58 & 58 & 57 \\
\hline October & 72 & 51 & 124 & 43 \\
\hline November & 81 & 67 & 226 & 51 \\
\hline December & 65 & 63 & 220 & 45 \\
\hline January & 86 & 62 & 197 & 60 \\
\hline February & 88 & 60 & 115 & 46 \\
\hline March & 72 & 54 & 180 & 48 \\
\hline Total & 502 & 59.6 & 1,120 & 49.7 \\
\hline
\end{tabular}

number of coytes present. Although some coyotes caught had undoubtedly moved into the area, it is felt that most were residents. Unless otherwise stated, the following analysis will be restricted to coyotes caught from September through March, 1963-64 through 1967-68. These fall and winter periods presumably encompass the breakup of litters, dispersal of young, prenuptial and breeding activities, and the first half of gestation.

Over the 5-year period, the seasonal catch of coyotes in the Uvalde area ranged from 400 to 500 , with the exception of 1966-67 when the catch rocketed to 850 (Table 8). In the area of light control, catch rates were considerably higher, averaging 2,290 coyote's per season. Reasons for the low catch in 1967-68 are unclear, but fewer than half the normal number of coyotes were reported. Varked differences in clistribution of the catch were evident betwern the light
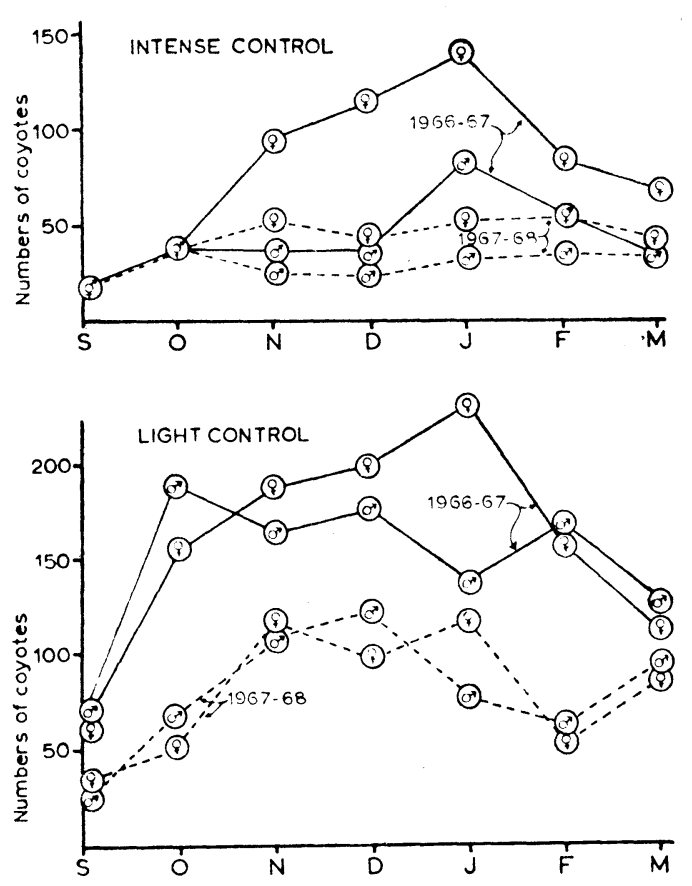

Fig. 4. Numbers of male and female coyotes captured September through March, 1966-67 and 1967-68, in areas of light and intensive control efforts.

and intensive control areas. Capture rates peaked in November in the light control area, with 49 percent of the coyotes taken between October and December. In the Uvalde area, more coyotes were captured in January than in any other month, with 56 percent of the seasonal catch taken between December and February (Table 8).

Further analysis revealed gross differences in the sex ratio between animals caught in areas of light and intensive reductional programs (1966-67 and 1967-68 only). Where the control program was less intense, the overall sex ratio (Table 9) was nearly equal ( 51.5 females to 48.5 males in 1966-67, 49.7 females to 50.3 males in 196769). With the exception of January 1967. the sex ratio among coyotes caught in the light control area remained nearly equal durine wed month (Figr 4). In contriast, 
females comprised 64.8 pereent of the eatch in the Uvalde arca (intensive control) in 1966-67, and 59.6 percent in 1967-68. In this case, males and females were caught in equal numbers during $S$ eptember and October, but from November through March, females outnumbered males sometimes as much as $3: 1$.

Interpretations at this point suggest that catch rates increased in September and October as coyotes became more active within their established ranges, and that infiltration into new areas became important in November, increased through January, and then decreased in intensity through March. Females appeared more prone to seek out new areas than males. This substantiates the observations of Robinson and Grand (1958), who reported mean recovery distances of 11.1 miles for tagged female coyotes and 7.9 miles for tagged males. They also pointed out that four of the five longest recoveries were by females, and of those recovered within 1 mile of thcir tagging site, males outnumbered females 42 to 27 . These interpretations contrast sharply with the findings of Phillips et al. (1972) concerning dispersal of red fox, where the frequency and distances recorded for males greatly exceeded those for females.

The infiltration rate of coyotes into the Uvalde area appeared greatest in January, coinciding with the period of prenuptial activities among coyotes. At that time, even males were caught more frequently than at other times. Cursory observations indicated that animals less than a year old were primarily involved, but a final judgment will be delayed until all problems associated with the analysis are resolved.

In the 1967-68 period, when the total catch in the area of light control was markedly lower than in previous years, the discrepancy in the sex ratio of animals caught in the Uvalde area was not as great and the catch was more evenly distributed throughout the season. This might indicate reproductive success, and hence population density, in surrounding areas as an important factor in dotermining infiltration rates, with females responding to a greater extent than males. An alternate hypothesis, suggesting that males sustain higher mortality rates prior to dispersal, does not appear consistent with the bulk of the information currently available.

For the present, estimates of the dispersal distances involved must be derived from the summary of tagging data provided by Robinson and Grand (1958). On the basis of two studies reported by them, the mean distances that tagged pups were recovered were 25.4 miles and 10.5 miles, respectively, although movements over 50 miles were not uncommon and several of 100 miles were noted. The averages listed above must be considered minimal, since the analysis did not distinguish between movements within established home ranges and movements of animals seeking new home sites.

\section{POPULATION MODEL}

The preceding information revealed some of the limits within which coyote populations can be expected to respond, and from them a model was developed (Fig. 5) as a basis for generating and testing additional hypotheses with regard to coyote populations and to serve as a provisional guide for implementing coyote management schemes. The model is derived from our experiences with coyotes primarily under southwestern desert and semidesert conditions but is believed to apply, with some modifications, to other situations.

In areas where coyote numbers have stabilized with respect to the environment in the absence of artificial restraints, populations may more than double with the 
spring whelping season (50 percent of females producing an average 4.5 to 5.0 viable young). Some neo-natal mortality is known to occur, but pup survival rates probably remain high for several months. In November, a gradual reduction in numbers begins both from mortality and through emigration to other areas. Emigration attains its greatest impact in January, when prebreeding activities reach their peak, but continues through the subsequent whelping season. As a result of dispersal and mortality, populations normally attain their lowest levels just prior to the whelping season. If we assume a 40 percent mortality of adults on an annual basis, a net survival of 33 percent of the young to 1 year of age is sufficient to maintain a stable population. The indicated loss of 67 percent of the young prior to their first birthday, through mortality and dispersal, does not seem unreasonable in view of our estimates of the fall population structure and an assumed small mortality among very young pups.

Under extremely favorable conditions (usually abundant food supply) or in areas where mortality rates are accelerated, populations may triple during the whelping season if, as suggested by Gier (1968), 75 percent of the females conceive an average of 6.0 viable pups. Ultimately this would be reflected in the mortality rates because population stability is incorporated in the model.

Under a regime of intensive population reduction, we can hypothesize that the population fluctuates around levels appreciably lower than those described above. Whelps should triple coyote numbers, but destruction of litters at dens would rapidly reduce the total number of coyotes. Since the efficiency of most control measures wanes through the summer, the rate of population reduction would decline. At lower densities, the stimulus for dispersal might be

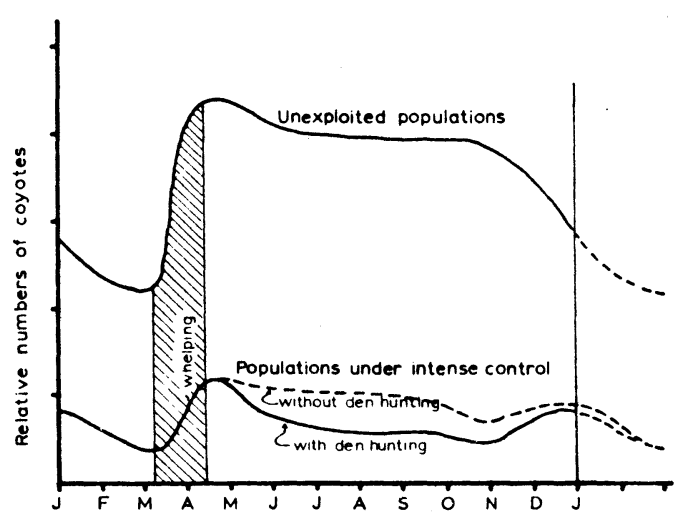

Fig. 5. Proposed model of the annual cycle of coyote num. bers under unexploited and intensive control regimes.

reduced, thus mitigating normal fall losses. By November, the number of coyotes may actually begin to increase again as a result of influx from surrounding areas, but control measures normally become more efficient during the fall and winter. Thus, the population is again reduced, reaching its lowest point just prior to the next whelping season. The precise nature of this curve would be dependent upon the type of control measures utilized as well as on the size of the area under control. If intensive den hunting was not utilized, the population might remain at the higher levels until other reductional techniques became effective in the fall. On the other hand, if a large area was involved, immigration from surrounding regions might not be detectable except along the fringes.

\section{MANAGEMENT IMPLICATIONS}

Since the current emphasis of coyote management is toward eliminating or avoiding hazards to human interests, I will stress control practices and attempt to point out features of normal coyote demographics that may be relevant. More specifically, I will explore time and place as factors in control technology that influence the effec- 
tiveness and efficioncy of programs. Although a specific facet of management-depredition control-will be the focus of this discussion, the model can be ergually useful in molderstanding ramifications of coyote biologey and the ceology of predation.

Like every management scheme, animal control must have specific objectives; the more preciscly they are identified, the more effectively they can be met. Four basic coyote control situations will be discussed here, although it is clear that real situations are seldom so distinct. The first situation recognizes occasional need for general population suppression to avoid epizootics or to preclude economic hazards, such as undue livestock harassment resulting from sheer numbers of coyotes. A second situation involves local problems of generally short duration, such as in the case of coyote depredations upon ripening watermelons or newborn calves. Another category consists of areas where coyotes pose perennial high risks, such as lambing ranges and sheep pastures, where the only suitable alternative appears to be extirpation of the predators. Until coyotes can be effectively and efficiently removed from the areas where intensive control is required, a fourth situation exists: the need to restrict infiltration from adjacent areas. Each of these problems is basically different, and each must be met in a separate way. Let us now turn to the model to see what it has to offer.

Almost by definition, we assume that whenever general population suppression is desired, relatively high densities are involved, possibly over extensive areas. Under such conditions, it could be anticipated that demographically the coyotes would be functioning similarly to unexploited populations (Fig. 5). Under these conditions, no facade of thoroughness in a program would be necessary, but quick appraisal suggests that there is little point in attempting to suppress numbers in the fall, when the population normally effects a 50 percent reduction within a brief period. Control efforts at that time merely supplant normal proceesses. Reduction belowe the point of popme. lation stability (carrying capacity?) would certainly invite immigration from adjacent arcas, when annual dispersal occurs. Where general suppression is warranted, it appears that removal would be most effective as dispersal wanes and immediately prior to the ensuing whelping season. Reductions then would be additive to natural losses and would also remove part of the incipient reproduction, hence making the effects more severe and presumably longer lasting than reductions at other times.

Spot control would seemingly fulfill the needs where coyotes cause temporary problems in local areas. When agricultural crops are involved, such as depredations on watermelons and cantalopes, the problems can be anticipated in advance and resolved on a local basis, whereas to achieve a similar degree of relief very far in advance would require a more massive approach over a larger area. However, a slow response to a temporary problem would do little more than salve one's wounds with a few dead coyotes. A control program in November would do little to protect a calving operation in October, for by the time the program was effective the calves would no longer be vulnerable. The population model counsels against expecting the effects of such a program to persist through the following year because of the resilience of populations. We are left with the alternative of meeting temporary and local problems on a temporary and local basis. In these instances it may be in order to let instant response capabilities of mobile programs replace more general and less efficient approaches.

Where coyotes create chronic problems 
among high-value commodities, there currently seems no alternative but to exclude them. Physical barriers can be helpful on small areas, but on larger expanses, intense population repression may be the preferred solution. Systematic reduction on a yearround basis would normally be anticipated. However, removal of coyotes just prior to whelping is more effective than at any other time, because part of the annual reproduction effort is removed simultaneously. Efforts at this time have the additional advantage of removing animals just prior to the period when depredations are traditionally the greatest. As a result of the low densities, few losses from natural causes would be expected. The second source of recruitment is immigration from surrounding populations, with some infiltration at all seasons but largely to be expected from December through February. Fortunately, most conventional control techniques are effective at that time.

Without the ability to remove offending individuals, or to otherwise curtail chronic problems, areas of intensive control are essential. Depending on the severity of the problem, establishment of buffer zones around high risk areas may be justified to reduce infiltration rates. Since coyotes presumably pose no threat to the buffer area itself, and juveniles are the ones most prone to seek new areas, the objective can be defined more precisely with a specific segment of the population being the primary target. This affords a wider choice of options, since any program that effectively removes some of the juveniles prior to dispersal should reduce egress to adjacent areas. It makes little difference if reduced egress is accomplished through the use of reproductive inhibitors to reduce recruitment rates, by denning to remove pups or by the use of conventional toole prine to the time novementecurs.
It has not been my intent to suggest when or where specific coyote control programs are justified or the means by which they should be accomplished, but rather to show how biological knowledge can assist in defining the problems in order to tackle them more directly and selectively. Managers must realize the values of the species, and they have the responsibility of evaluating circumstances and identifying problemsto understand, for example, the basic differences between protecting seasonal versus year-round calving operations, or the significance of the type of fencing used. Managers also must recognize the relative merits and hazards of each control technique, be it trapping, shooting from aircraft, or use of a toxicant. It is the managers who must decide the time, place, and intensity of effort. Coyote control programs are frequently subject to economic, social, and political ramifications beyond the scope of this presentation; but despite the limitations these factors may impose, it is our biological knowledge of the animal that permits us to isolate, identify, and resolve the areas of conflict within species management. Ultimately, the application of species biology will provide the finesse that will allow us to alleviate hazards to other human endeavors and yct provide ample opportunity for the recreational and aesthetic pursuits that coyotes offer.

\section{LITERATURE CITED}

Bennitt, R. 1948. The coyote bounty system in Missouri, 1936-1947. Trans. N. Am. Wildl. Conf. 13:314-321.

Crimistian, J. J. 1956. Adrenal and reproductive responses to population size in mice from freely growing populations. Ecology 37(2): $258-273$.

1959 (1958). The roles of endocrine and behavioral factors in the growth of mammalian populations. Pages 71-97. In A. Gonman Editor!, Comparative endocrinolo.y. Th Wilry \& Sons, Inc., New York, and ( Harian \& Hall, I.td., London. 746p) 
Clark, F. W. 1972. Influence of jackrabbit density on coyote population changes. J. Wildl. Mgmt. 36(2):343-356.

Errington, P. L. 1946. Predation and vertebrate populations. Quart. Rev. Biol. 21(2): 144-177, 21(3):221-245.

GIER, H. T. 1968. Coyotes in Kansas. Revised. Kansas State Coll. Agr. Expt. Sta. Bull. 393. $118 \mathrm{pp}$

Hamlett, G. W. D. 1938. The reproductive cycle of the coyote. U. S. Dept. Agr. Tech. Bull. 616. $11 \mathrm{pp}$.

Linhart, S. B., and F. F. Knowlton. 1967. Determining age of coyotes by tooth cementum layers. J. Wildl. Mgmt. 31(2):362-365.

, H. H. Brusmann, AND D. S. Balser. 1968. Field evaluation of an antifertility agent, stilbesterol, for inhibiting coyote reproduction. Trans. N. Am. Wildl. and Nat. Resources Conf. 33:316-327.

LUETH, F. X. n.d. Alabama's predator studies. Alabama Dept. of Conserv. P-R Rept., Project 35-R.

Phillips, R. L., R. D. Andrews, G. L. Storm, and R. A. Bishop. 1972. Dispersal and mortality of red foxes. J. Wildl. Mgmt. 36(2):237-248.
Pimlote, D. H., And P. W. Joslin. 1968. The status and distribution of the red wolf. Trans. N. Am. Wildl. and Nat. Resources Conf. 33: 373-388.

Robinson, W. B. 1943. The "Humane Coyotegetter" vs. the steel trap in control of predatory animals. J. Wildl. Mgmt. 7(2):179-189. -1961. Population changes of carnivores in some coyote-control areas. J. Mammal. $42(4): 510-515$.

- and M. W. Cunmings. 1951. Movements of coyotes from and to Yellowstone $\mathrm{Na}$ tional Park. U. S. Fish and Wildl. Serv. Spec. Sci. Rept.:Wildl. No. 11. 17pp.

- AND E. F. Grand. 1958. Comparative movements of bobcats and coyotes as disclosed by tagging. J. Wildl. Mgmt. 22(2):117-122.

Rogers, J. G. 1965. Analysis of the coyote population of Dona Ana County, New Mexico. M. S. Thesis. New Mexico State Univ. 39pp.

Young, S. P., AND H. H. T. Jackson. 1951. The clever coyote. The Stackpole Company, Harrisburg, Pennsylvania, and the Wildlife Management Institute, Washington, D. C. $411 \mathrm{pp}$.

Received for publication April 30, 1971. 